\title{
$\mathrm{IMO}$ 마리타임 클라우드 분석을 통한 AIS응용 프로그램 구현 및 테스트
}

이재욱*, 문창호**, 이서정***

요 약

$\mathrm{IMO}$ 의 이-내비게이션은 안전항해와 해양환경 보호를 위해 진행중인 프로젝트이다. 이-내비게이션의 전략 이행 계획 중 마리타임 클라우드라는 프로젝트가 존재한다. 마리타임 클라우드는 해양 이해관계자 들 간의 정보교환을 위한 IT 프레임워크 기술이다. 마리타임 클라우드의 아키텍처와 클라이언트 프로그 램인 $\mathrm{EPD}$ 를 분석하여 구조, 동작방식 등을 파악하였으며 이를 통해 실제 클라이언트 프로그램을 구현 하였다. 클라이언트 프로그램으로는 현재 AIS-ASM을 통해 제공되고 있는 서비스인 정박정보(Berthing Data)를 대상으로 마리타임 클라우드의 메시지 전달 기능인 MMS 서비스를 이용해 데이터 교환이 이루 어질 수 있는지 테스트하였다. 테스트 결과 MMS 서비스를 이용한 데이터 교환에 성공하였으며 이는 향후 마리타임 클라우드 서비스 개발에 도움이 될 수 있으며, 한국형 마리타임 클라우드 개발에 기여할 수 있다.

키워드 : 마리타임 클라우드, MMS, EPD, AIS-ASM, 정박정보

\section{AIS application program implementation and test based on IMO Maritime Cloud analysis}

\author{
Jea-Wook Lee*, ChangHo Mun**, Seojeong Lee***
}

\begin{abstract}
IMO e-Navigation is ongoing project for safety navigation and protection of maritime environment. Maritime Cloud is a part of e-Navigation Strategy Implementation Plan. It is IT framework technology for exchanging information among maritime stakeholders. We found configuration and operation process by analysis on Maritime Cloud architecture and EPD which is a client program. Through the result, we actually implemented client program. Client program targets Berthing data serviced on AIS-ASM. And we used MMS which is function of message exchanging of Maritime Cloud. The test result show data exchanging succeeded. And it will be helpful to develop Maritime Cloud service, to advance Korean Maritime Cloud.
\end{abstract}

Keywords : Maritime Cloud, MMS, EPD, AIS-ASM, Berthing data

\section{Introduction}

※ Corresponding Author: Seojeong Lee

Received : December 10, 2015

Revised: December 28, 2015

Accepted : December 31, 2015

* GMT, InC

** Korea Maritime and Ocean University, Division

of IT Engineering

*** Korea Maritime and Ocean University, Division

of Maritime IT Engineering

Tel: $+82-51-405-4888$

email:kmousqa@gmail.com
IMO (International Maritime Organization) is

$\square$ This Research is the outcome of the "Base Study of Marine Accident Prevention System (Phase 2)' project sponsored by the Korean Ministry of Ocean and Fisheries.

- This Research is the outcome of the 'The New Product/Technology Development Projects with a Purchase Condition' project sponsored by the Small and Medium Business Administration. 
currently carrying out $\mathrm{e}^{-N a v i g a t i o n}$ project to support safe navigation and protect marine environment. The purpose of e-Navigation is to exchange data between the ground and vessel, integrate vessel equipment, and improve the reliability of navigation data. Maritime Cloud is implemented as part of SIP (Strategy Implementation Plan).

Maritime Cloud is the IT framework based SOA (Service Oriented Architecture) for standard, infrastructure and governance with the purpose of safe data exchange among maritime stakeholders[1].

Furthermore, it implements a client program based on the analysis and tests it to prepare for future development of an $\mathrm{e}^{- \text {Navigation }}$ application service.

AIS is one of the services of providing the vessel location data and other navigation data. Under the provisions of SOLAS (Safety of Life at Sea) Convention requires AIS to be fitted aboard ships with gross tonnage (GT) of 500 or more and international navigating ships and passenger ships with GT of 300 or more. The AIS message is used to transmit the binary messages that can contain the location report, base station report and other data. There are various MSI (Maritime Safety Information) services using the message nos. 6 and 8 to transfer the binary message [2].

AIS-ASM is specified for the applications such as services related to weather, route and tide using the AIS binary messages. It also includes the specific information related to dangerous cargo, number of persons on board, berthing information, etc. The list of services using ASM can be checked in IMO SN.1/Circ.289 and web page www.e-navigation.nl/asm.

After realizing that the TCP and UDP protocols alone are not sufficient to satisfy the requirement of maritime communication, Maritime Cloud has a plan to develop a better service delivery environment by supporting
AIS-ASM. This paper implemented and tested a client system providing the berthing data message, which is one of messages provided by AIS-ASM, using Maritime Cloud's message exchange service MMS (Maritime Messaging Service).

\section{Related Researches}

\subsection{Maritime Cloud}

The key functions of Maritime Cloud include MSP (Maritime Service Portfolio), MIR (Maritime Identity Registry) and MMS.

MSP uses the service registry to help the service providers, service users and related stakeholders easily register, search and use the services.

MIR identifies and manages the stakeholders using Maritime Cloud. It groups the vessel side users and maritime side users, categorizes the vessels and organizations, and then assigns ID to each of them.

MMS facilitates the exchange of message in text or XML form between the clients identified by MIR. Currently, only the MMS function is implemented in Maritime Cloud while MSP and MIR are being developed with the defined concept. In addition, Maritime Cloud supports various communication protocols such as TCP (Transmission Control Protocol), UDP (User Datagram Protocol) and AIS(Automatic Identification System) as well as the integrated and reliable communication framework.

Maritime Cloud is an open source based project and can be checked in Github (http://github.com/MaritimeCloud). Github provides the web based project hosting service and supports version management, source code management and change history management.

This study used the project code issued on June 32015 and analyzed the architecture using the reverse engineering tool EA (Enterprise Architecture). 


\subsection{EfficienSea}

The purpose of EfficienSea 2 project is to jointly develop the innovative solutions for safe and efficient maritime service. It is a consortium to develop and implement the communication framework Maritime Cloud to be used for information sharing, marine traffic management, e-maritime, e-navigation environment and maritime IoT. It is participated by government agencies, international organization, leading enterprises and domain experts in the countries in the Baltic Rim.

\subsection{MCSA}

MCSA (Maritime Cloud Service Agency) is a system jointly developed by the Software Engineering Lab at Korea Maritime and Ocean University and Korea Research Institute of Ships and Ocean Engineering (KRISO) for seamless data exchange between heterogeneous systems. It is an agent that supports data exchange by formatting data between a Maritime Cloud service and other systems using the web socket and JSON.

\section{Analysis of Maritime Cloud Client}

This study analyzed the currently implemented MMS, which is messaging function of Maritime Cloud, and the client program EPD (e-Navigation Prototype Display). For the MMS, the component structure, class structure and relation and functionalities for MMS architecture were analyzed using the software engineering tool EA.

EPD is a Maritime Cloud application that will be the offshore and onshore client system in the test bed for demonstration of e-Navigation[3]. EPD was analyzed to check the prerequisite tasks as well as the system operating architecture and process for using Maritime Cloud in client system.

\subsection{MMS}

(Figure 1) Component of the MMS

\begin{tabular}{|c|c|}
\hline \multicolumn{2}{|c|}{ Maritime Messaging Service } \\
\hline Server & Client \\
\hline $\begin{array}{l}\text { Client connection, } \\
\text { Message broadcasting, } \\
\text { Security and location } \\
\text { tracking }\end{array}$ & $\begin{array}{l}\text { MMS login and } \\
\text { termination, ID setting, } \\
\text { Communication } \\
\text { exception handling }\end{array}$ \\
\hline \multicolumn{2}{|l|}{ Common } \\
\hline \multicolumn{2}{|c|}{$\begin{array}{l}\text { Client management and message delivery, } \\
\text { Common components of server and client. }\end{array}$} \\
\hline
\end{tabular}

(Figure 1) shows the components of MMS: Common, Server and Client. The Common component connects the functions of server and client, manages the client and delivers the messages. The Server component operates the server delivering the message which is the key function of MMS. The component also connects the clients and has the broadcasting function. The Client component operates the client receiving the MMS service and has the function to login the server and set ID[4].

(Figure 2) Layer of MMS Server

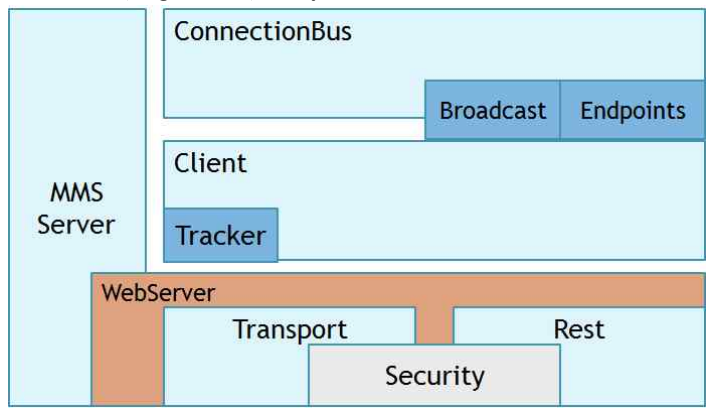

(Figure 2) shows the operating layers of the server component. The server operation begins with web based server environment setting through the MMS server and web server, which play a role as setting, beginning, and stopping of server. It transmits and receives the messages through the Transport, Rest and 
Security. The geo-messaging service, which handles location tracking and location based connection, is enabled with the client component which manages the connected client sessions and the Tracker module which tracks the location of client and information of transmitter/receiver. The Broadcast and Endpoints modules manages the terminal points and sets up broadcasting while the ConnectionBus module delivers the messages[4].

On research [4], proceeded research on operation structure and process by analyze source code that is open source ongoing project for demonstration of MaritimeCloud on IMO. This research develop a service using maritime environment. And it is based on MaritimeCloud.

(Figure 3) Connecting process of Maritime Cloud

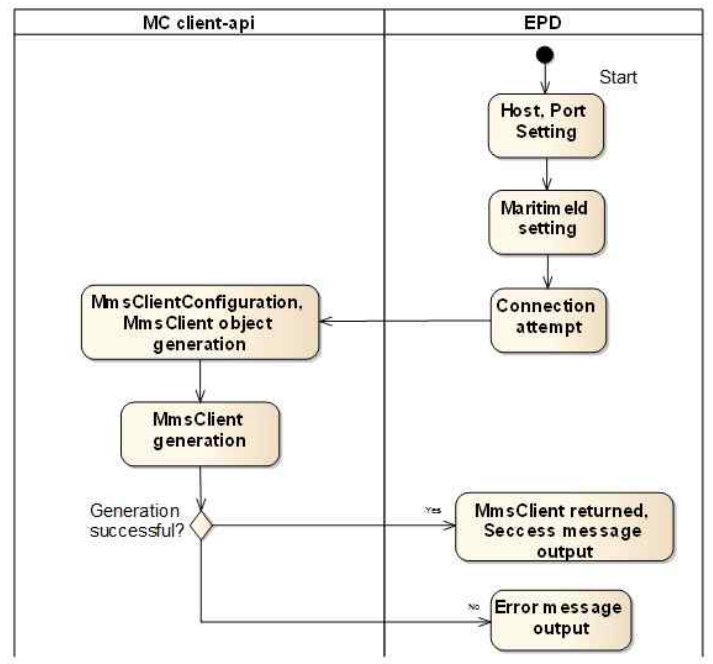

\section{$3.2 \mathrm{EPD}$}

EPD consists of the offshore client EPD-ship, the onshore client EPD-shore, and the common functions common and Util. The offshore client EPD-ship was analyzed to study how the client system uses Maritime Cloud and in which sequence it is operated. EPD can connect to Maritime Cloud using the client component of Maritime Cloud[4].

(Figure 3) shows the process of EPD-ship connection to Maritime Cloud. The host and port are set to connect Maritime Cloud, and the connection signal is sent to Maritime Cloud. Upon receiving the signal, Maritime Cloud generates the MmsClient object in the MmsConfiguration class of the ClientApi component. When the object is successfully generated, the MmsClient data are sent to the client.

\section{Berthing Data Scenario and Implementation}

Berthing data service including berthing request by a vessel or berthing approval by the berth through a specifically formatted message is one of the services which are provided by AIS-ASM.

Table 1 summarizes the parameters and the number of bits and description of each parameter of berthing data. A vessel sends the message to request berthing while the base station sends the message as a way of approval. The message is organized of 360 bits of binary data. DAC (Designated Area Code) and FI (Function Identifier) of IAI (International Application Identifier) are fixed values and use 001 and 20, respectively[5].

<Table 1> Message Protocol of Berthing Data

\begin{tabular}{|c|c|c|}
\hline Parameter & $\begin{array}{l}\text { No. of } \\
\text { bits }\end{array}$ & Description \\
\hline $\begin{array}{c}\text { Message } \\
\text { ID }\end{array}$ & 6 & $\begin{array}{l}\text { Identifier for } 6 \text { bit message; } \\
\text { always } 6 \text {. }\end{array}$ \\
\hline $\begin{array}{l}\text { Repeat } \\
\text { Indicator }\end{array}$ & 2 & $\begin{array}{l}\text { Used by the repeater to } \\
\text { indicate how many times a } \\
\text { message has been repeated. } \\
0 \sim 3 \\
0=\text { default } \\
3=\text { no more additional repetition }\end{array}$ \\
\hline & 30 & MMSI $\quad$ (Maritime $\quad$ Mobile \\
\hline Source II & 30 & Service Identity) number of \\
\hline
\end{tabular}




\begin{tabular}{|c|c|c|}
\hline & & source station \\
\hline $\begin{array}{l}\text { Sequence } \\
\text { Number }\end{array}$ & 2 & $\begin{array}{l}\text { Repeated message number } \\
\text { O } 3 \text {; refer to ITU-R M.1371-3, } \\
\text { Annex } 2, \S 5.3 .1 \text {. }\end{array}$ \\
\hline $\begin{array}{l}\text { Destination } \\
\text { ID }\end{array}$ & 30 & $\begin{array}{l}\text { MMSI number of destination } \\
\text { station }\end{array}$ \\
\hline $\begin{array}{l}\text { Retransmit } \\
\text { ID }\end{array}$ & 1 & $\begin{array}{l}\text { Retransmit flag } \\
0=\text { no retransmission } \\
=\text { default } \\
1=\text { retransmitted message }\end{array}$ \\
\hline Spare & 1 & Not used, set to zero \\
\hline IAI & 16 & $\mathrm{DAC}=001 ; \mathrm{FI}=20$ \\
\hline $\begin{array}{c}\text { Message } \\
\text { Linkage ID }\end{array}$ & 10 & $\begin{array}{l}\text { Segment number for additional } \\
\text { information, transmitted with } \\
\text { MMSI number } \\
\quad 1^{\sim} 1,023 \\
0=\text { not available=default }\end{array}$ \\
\hline Berth Length & 9 & $\begin{array}{l}\text { Berth length, in } 1 \text { meter steps } \\
1 \sim 510 \text { meters } \\
511=411 \text { meters or longer } \\
0=\text { undefined }=\text { default }\end{array}$ \\
\hline $\begin{array}{l}\text { Water Depth } \\
\text { at Berth }\end{array}$ & 8 & $\begin{array}{l}\text { Water depth at berth, in } 0.1 \\
\text { meter steps } \\
0.1 \sim 25.4 \text { meters } \\
255=25.5 \text { or greater } \\
0=\text { undefined=default }\end{array}$ \\
\hline $\begin{array}{l}\text { Mooring } \\
\text { Position }\end{array}$ & 3 & $\begin{array}{l}0=\text { undefined=default } \\
1=\text { port-side to } \\
2=\text { starboard }- \text { side to } \\
3=\text { Mediterranean mooring } \\
4=\text { mooring buoy } \\
5=\text { anchorage } \\
6 \sim 7 \text { (reserved for future use) }\end{array}$ \\
\hline $\begin{array}{l}\text { Berth } \\
\text { Date and } \\
\text { Time }\end{array}$ & & UTC date and time \\
\hline $\begin{array}{l}\text { UTC } \\
\text { Month }\end{array}$ & 4 & $\begin{array}{l}1 \sim 12 \\
0=\text { not available }=\text { default }\end{array}$ \\
\hline UTC Day & 5 & $\begin{array}{l}1 \sim 31 \\
0=\text { not available }=\text { default }\end{array}$ \\
\hline $\begin{array}{l}\text { UTC } \\
\text { Hour }\end{array}$ & 5 & $\begin{array}{l}0 \sim 23 \\
24=\text { not available }=\text { default }\end{array}$ \\
\hline $\begin{array}{c}\text { UTC } \\
\text { Minute }\end{array}$ & 6 & $\begin{array}{l}0 \sim 59 \\
60=\text { not available=default }\end{array}$ \\
\hline $\begin{array}{l}\text { Services } \\
\text { availability }\end{array}$ & 1 & $\begin{array}{l}\quad 0=\text { service } \\
\text { unknown=default; set all "Type } \\
\text { of Services Available" indicated } \\
\text { below to zero } \\
1=\text { service types are } \\
\text { known }\end{array}$ \\
\hline $\begin{array}{l}\text { Type of } \\
\text { Services } \\
\text { Available }\end{array}$ & 52 & $\begin{array}{l}\text { Available services at berth. } \\
\text { Each service described with } 2 \\
\text { bits, coded as: } \\
0=\text { service not available or } \\
\text { requested = default }\end{array}$ \\
\hline
\end{tabular}

\begin{tabular}{|c|c|c|}
\hline & & 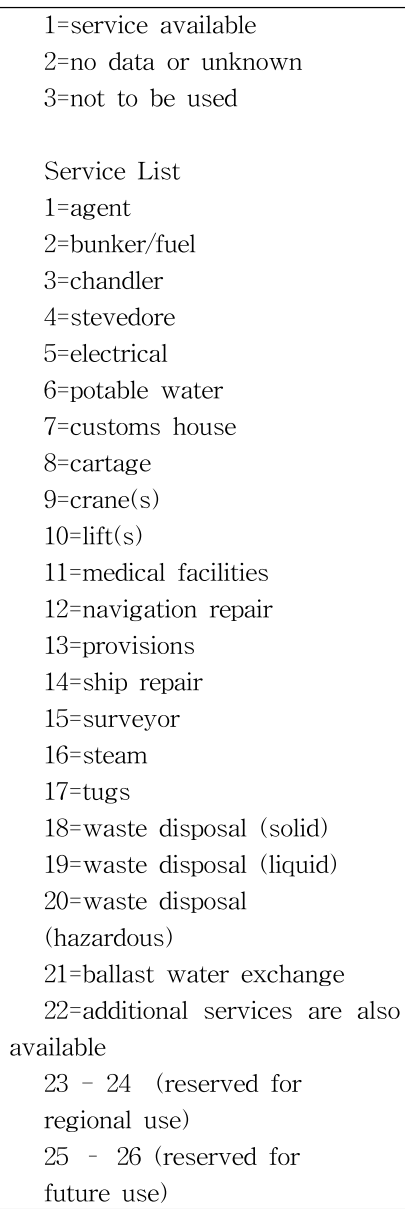 \\
\hline $\begin{array}{c}\text { Name of } \\
\text { Berth }\end{array}$ & 120 & $\begin{array}{l}20 \text { characters } 6 \text { bits ASCII, as } \\
\text { defined in ITU-R M. 1371-3, } \\
\text { Table } 44 \text {. }\end{array}$ \\
\hline $\begin{array}{l}\text { Centre } \\
\text { position of } \\
\text { Berth, } \\
\text { Longitude }\end{array}$ & 25 & $\begin{array}{l}\text { Longitude in } 1 / 1,000 \text { min, } \pm 180 \\
\text { degrees as per } 2 \text { 's complement } \\
\text { (East }=\text { positive, West }= \\
\text { negative). } \\
\quad 181=\text { not available= default }\end{array}$ \\
\hline $\begin{array}{l}\text { Centre } \\
\text { position of } \\
\text { Berth, } \\
\text { Latitude }\end{array}$ & 24 & $\begin{array}{l}\text { Latitude in } 1 / 1,000 \text { min, } \pm 90 \\
\text { degrees as per } 2 \text { 's complement } \\
\text { (North }=\text { positive, South }= \\
\text { negative). } \\
\quad 91 \text { degrees }=\text { not } \\
\text { available= default }\end{array}$ \\
\hline Spare & 0 & Not used. Set to zero. \\
\hline Total & 360 & \\
\hline
\end{tabular}

(Figure 4) shows the berthing data service scenario. The offshore client system finds the base station that can process the service. When a berth is found, it sends the berthing 
request using the berthing data message to the base station. When the response by the base station is received, the offshore client outputs it on the screen.

(Figure 4) Berthing data scenario

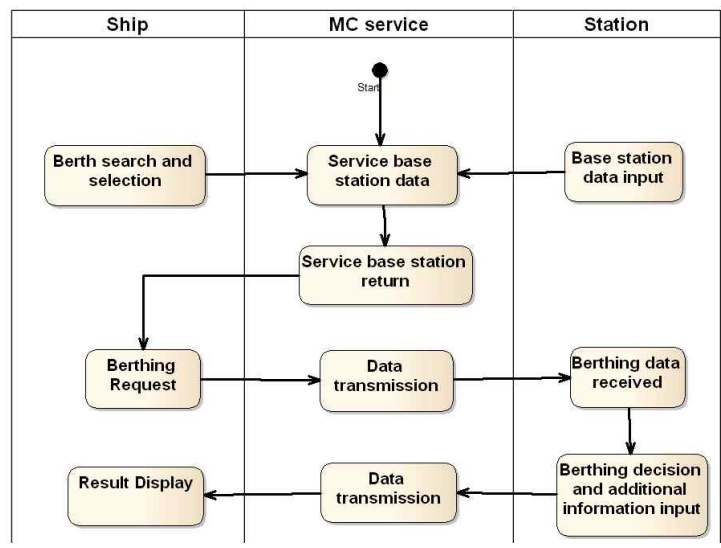

The onshore client system inputs the base station data and displays the request message on the screen when it is received from a vessel. Upon approval of berthing, it sends the berthing data in the specific format to the vessel. If the berthing request is denied, it sends the message composed only of default values.

This study implemented a Maritime Cloud based berthing service test program to check if the message specific to the berthing data form could be generated and if the data could be successfully exchanged using the MMS function of Maritime Cloud. (Figure 5) shows the algorithm of the implemented program for this study.

System interface is designed for user convenience and accurate expression by considering systemicity, economy, intelligibility, consistency. To satisfy them, we consider accordance of font, color, arrangement and movement of sight[6].

(Figure 6) shows the operating screen of offshore berthing service client. The user specifies the basic vessel data for the message in the left side of screen and click the SendButton to send the message. Upon the request, the message in the specific data format is generated and transferred to the base station on ground. When the response from the base station is received, the information is displayed on the right side of screen. The right side of the screen displays the basic information (depth of water, location, list of available services, etc.) of the berth.

(Figure 5) Algorithm of the implemented program

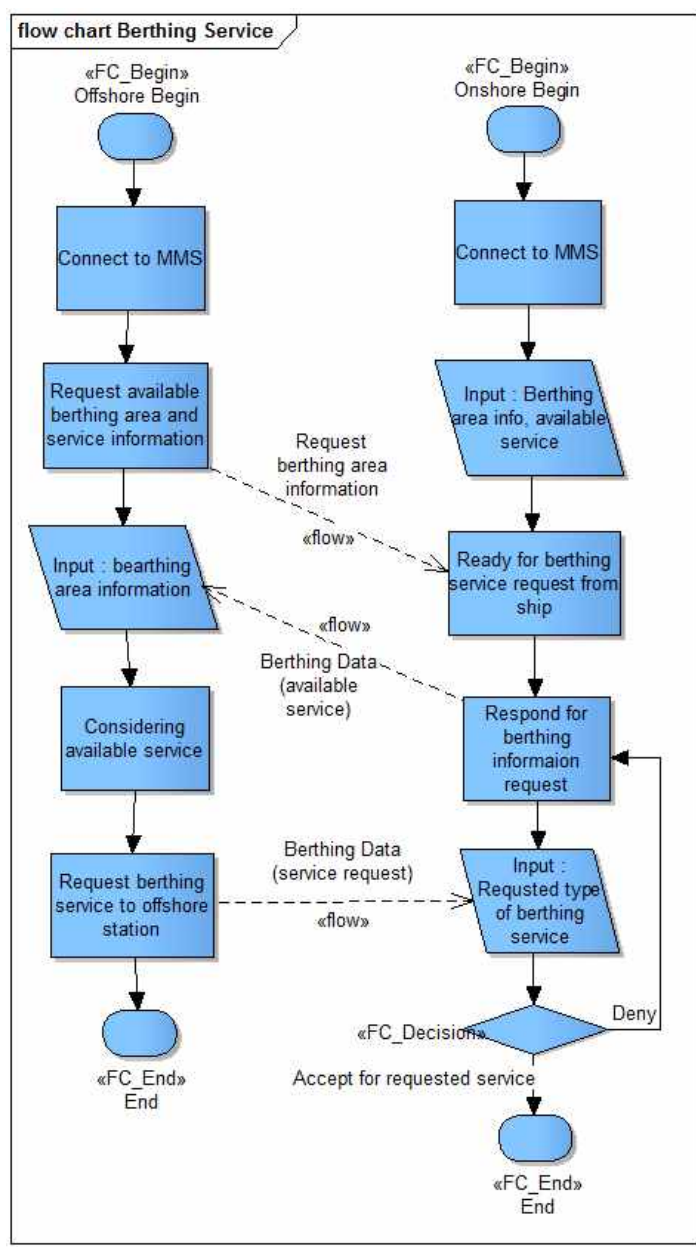

(Figure 7) shows the onshore management client. The basic information (berth length, 
(Figure 6) Berthing service test program for offshore

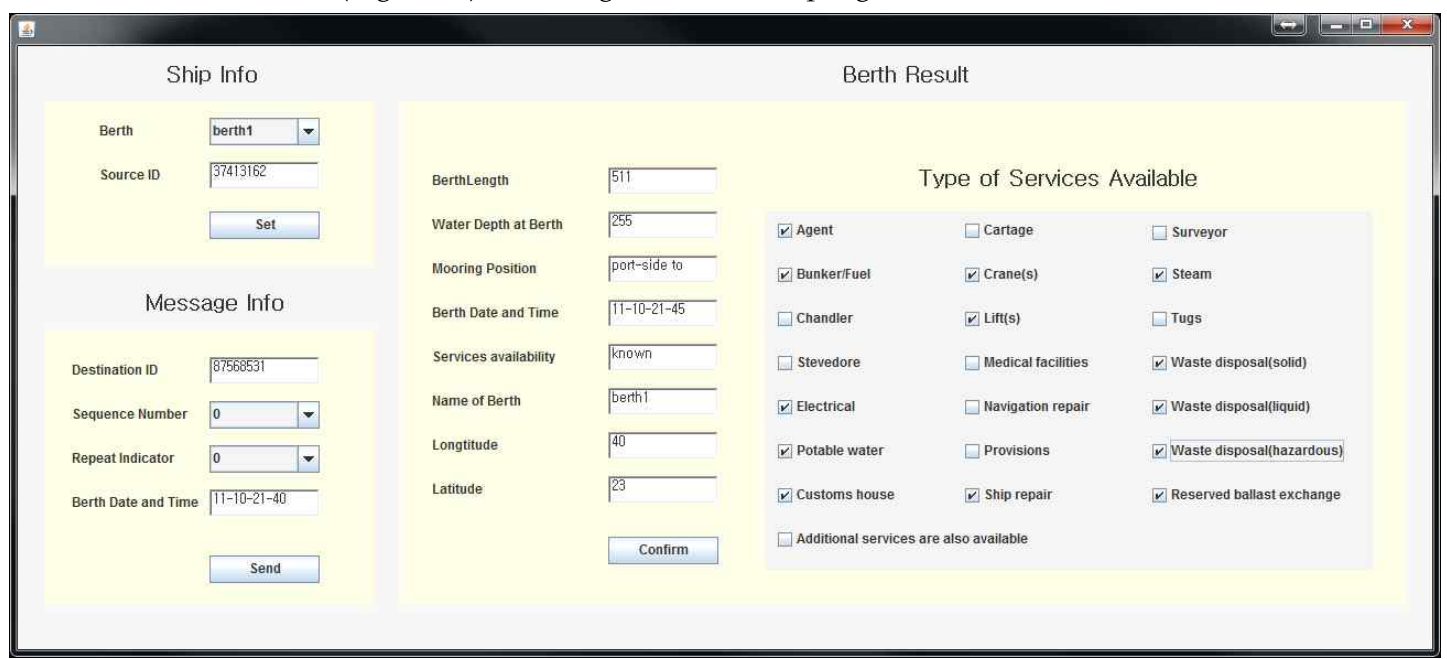

(Figure 7) Berthing service test program for onshore

\begin{tabular}{|c|c|c|c|c|c|c|c|}
\hline 要 & & & & & & & $\Leftrightarrow \Rightarrow$ \\
\hline \multicolumn{2}{|c|}{ Berth Info } & \multicolumn{6}{|c|}{ Request Info } \\
\hline & & Ship & Ship1 & 1 & \multicolumn{3}{|c|}{ Type of Services Available } \\
\hline BerthLength & 511 & Destination ID & \multicolumn{2}{|l|}{37413162} & \multirow{2}{*}{$\begin{array}{l}\nabla \text { Agent } \\
\nabla \text { Bunkerifuel }\end{array}$} & \multirow{2}{*}{$\begin{array}{l}\square \text { Cartage } \\
\nabla \text { Crane(s) }\end{array}$} & \multirow{2}{*}{$\begin{array}{l}\square \text { Surveyor } \\
\square \text { Steam }\end{array}$} \\
\hline Name of Berth & berth1 & Sequence Number & 0 & - & & & \\
\hline Longtitude & 40 & Repeat Indicator & 0 & 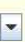 & $\square$ Chandler & $\nabla$ Lift(s) & $\square$ Tugs \\
\hline Latitude & 23 & Berth Date and Time & $\mid 11-10-21-45$ & & $\square$ Stevedore & $\square$ Medical facilities & $\nabla$ Waste disposal(solid) \\
\hline \multirow[t]{4}{*}{ Source ID } & 87568531 & Water Depth at Berth & 255 & & $\nabla$ Electrical & $\square$ Navigation repair & $\nabla$ Waste disposal(liquid) \\
\hline & \multirow{3}{*}{ Set } & Mooring Position & port-side to & - & \multirow{2}{*}{$\begin{array}{l}\text { v Potable water } \\
\text { v Customs house }\end{array}$} & $\square$ Provisions & $\nabla$ Waste disposal(hazardous) \\
\hline & & Services availability & known & - & & $\nabla$ Ship repair & V Reserved ballast exchange \\
\hline & & \begin{tabular}{|l|} 
Deny \\
\end{tabular} & Accept & & \multicolumn{2}{|c|}{$\square$ Additional services are also available } & \\
\hline
\end{tabular}

depth of water, location, etc.) of the berth is displayed and the vessel that requested berthing can be selected in the left side of the screen. The user inputs additional data of the vessel and then click the AcceptButton to generate the approval message and send it to the vessel or click the DenyButton to generate a message composed of default values and send the denial message to the vessel.

\section{Implementation results and Conclusion}

In this paper analyzed Maritime Cloud which

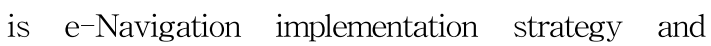


developed the actually serviced berthing data on Maritime Cloud using the analysis result. It also analyzed the MMS service of Maritime Cloud and the client system EPD to check the architecture of Maritime Cloud, server operation, connection by client system, access to Maritime Cloud by client, and MMS service use. Based on the understanding, a message in the berthing data format, which was one of AIS-ASM services, was generated and the message transfer was conducted in accordance with a scenario. The implementation result showed that the data were successfully exchanged using the MMS service of Maritime Cloud.

The result of this study will be used for enhancing system operation and operation scheme and for expanding the services for navigation safety and to eventually for development of Maritime Cloud in Korea.

\section{References}

[1] International Maritime Organization(2014), Overvie w of the Maritime Cloud concept, IMO NCSR 1/INF. X, April, 2014

[2] G. Kim, G. Park, "Preliminary Researches for the Dep loyment of New AIS-ASM Services", Journal of Ko rea Institute of Information and Communication Eng ineering, Vol.17, No.7, pp.1515-1521, July, 2013.

[3] J. Lee, H. Kim, S. Woo, S. Lee, "Reverse Engineering of Open Source e-Navigation Software Using Enter prise Architect", Proceedings of Autumn 2014 Confe rence of Korean institute of Navigation and Port Res earch, pp.47-49, October, 2014.

[4] J. Lee, C. Mun, S. Lee, "Analysis of IMO Maritime Cloud Client for Development of e-Navigation Appli cation Service", Proceedings of Autumn 2015 Confer ence of Korean institute of Navigation and Port Res earch, pp.5-6, October, 2015.

[5] International Maritime Organization, Guidance on th e user of AIS Application-Specific Messages, IMO
SN.1/Circ.289, June, 2010.

[6] H. Hwang, T. Kim, H. Park, J. Lee, S. Lee, "A User Interface Designing Guideline for Shipboard Integra tion Monitoring", Journal of Digital Contents Societ y, Vol.12, No.3, pp.391-396, September, 2011.

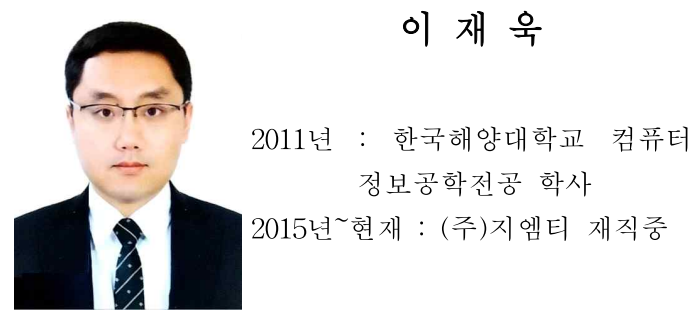

관심분야 : MaritimeCloud, GMDSS

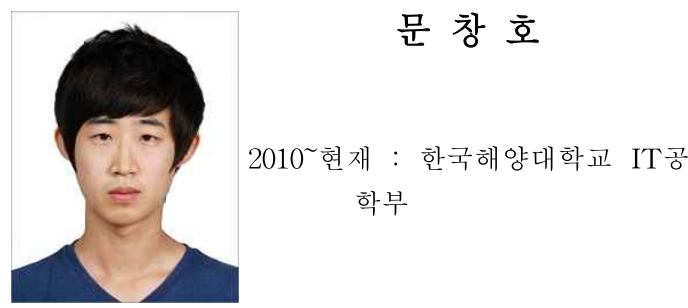

관심분야 : 해양 소프트웨어, $\mathrm{e}^{-}$Navigation

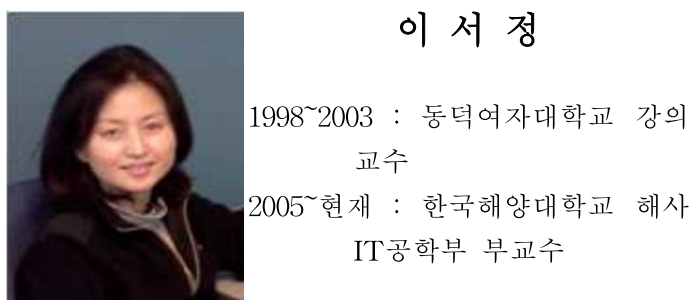

2010 현재 : 한국IT서비스학회 이사

2008 현재 : 국토해양부 IMO 항해안전 전문위원회 및 항해통신 - 수색구조 전문위원회 정부대표 단

관심분야 : 소프트웨어 개발 방법론, 소프트웨어 통 합, $\mathrm{e}^{-N a v i g a t i o n ~ ㅅ ㅗ ㅍ ㅡ ㅌ ㅡ ㅇ ㅞ ㅇ ㅓ ~ ㅍ ㅜ ㅁ ㅈ ㅣ ㄹ ~}$ 